MA U N O Ko S K I

\title{
Aleksis Kiven Keinu-runon Onnela
}

Aleksis Kiven runo Keinu (kok. Kanervala, 1866) on kaksitasoinen, siten että sä/keistöjen neljä ensimmäistä säettä sisältävät aluksi reaalisen maisemakuvan ja siitä asteittain muuttuvan ja täsmentyvän Onnela-kuvitelman. Kertosäkeiden tehtävänä on kiinnittää runo lähtökohdassa mainittuun aikaan ja paikkaan ja samalla korostaa varsinkin loppupuolen pääsäkeiden kuvittelunomaisuutta. Voidaan myös sanoa, että niillä on kehyskertomuksen merkitys. Runossa on toinenkin, pääsäkeitä koskeva kahtiajako. Neljä ensimmäistä säkeistöä sisältävät keinunnan ja siihen liittyvän tunnelman kuvauksen, kolme jälkimmäistä säettä Onnela-käsitteen määrittelyn. Jos runon varsinaisena sanomana pidetään kyseistä käsitteenmäärittelyä, alkuosalle jää tilaisuuden luomisen funktio. Siinäkin tapauksessa, että runon painopiste nähtäisiin toisaalla, so. sitä pidettäisiin keinumäen idyllinä ja Onnelaa vain senkertaisen idyllin synnyttämänä haavekuvana, edellä mainitut jaot ovat olennaisia runon struktuurille.

Onnela-kuvan hallitsevaa asemaa runossa osoittaa sekä immen että keinun asteittainen siirtyminen ensimmäisen säkeistön aivan keskeisestä asemasta taka-alalle ja lopulta vain kertosäkeisiin. Neito on passiivinen mukanaolija, jota runoilija on tarvinnut kuvitelmaansa varten. V. A. Koskenniemi pitää keinua ponnahduslautana haaveellisen Onnelan maahan, ja hän puhuu samalla rokokoon suosiman eroottisen keinun luonnonraikkaasta vastineesta. ${ }^{1}$ Runo ei ainakaan välittömästi viittaa edes lemmenkuvitelmaan; tuskin Kivi on keinuntaa lentona kuvatessaan ajatellut mitään. sellaista, minkä psykoanalyytikot myöhemmin olisivat voineet tulkita omalle symbolikielelleen, jossa

1 V. A. Koskenniemi, Aleksis Kivi, s. 138--139. 
lentäminen (unena) merkitsee coitusta. Tosin runo olisi niinkin helppo selittää. On huomattava, että Kiven rakkausrunot, varsinkin subjektiiviset, ovat korkealla maanpinnan yläpuolella liikkuvia valveunia, kuten Paavo E. S. Elo on sanonut. ${ }^{2}$ Runon aavistuksenomainen eroottispohjaisuus on vain onnentunteen varsin käypä baasis.

Keinunta maan ja taivaan välillä on luonnollinen mielikuva, kun ajatellaan hämäläistä kyłäkeinua korkealla mäellä. Kohoaminen maan pinnasta korosta onnentunteen kehittelyyn sopivaa, taivasta tavoittavaa motiivia. Keinunnan kuvitellaan tapahtuvan "tuulien viileäs helmas", ja se vaihtuu ensimmäisen osan loppusäkeistössä toiveeksi lentää "siivillä läntisen" keinujan Onnelana näkemään paikkaan." Koska tuuli on, paitsi vievä, myös vilvoittava, se korostaa runoilijan pyrkimystä fyysisen tunnelatautuman eliminoimiseen.

Varsinainen Onnela-kuvitelma lähtee liikkeelle maisemasta, jota Kivi tarkastelee useimmiten korkealta. Konkreettista maisemaa katsoessaan hän vangitsee laajoja yleisnäkymiä kaikista ilmansuunnista, mutta Onnela-kuvitelmassa katse suuntautuu vain yhteen kohteeseen : "kaukana näen mä kaunoisen kunnaan". Runon rakennetta hallitsee kiinteä, ikään kuin heilahduksittain etenevä, kohteen täsmennyksestä muodostuva sarja. Kysymyksessä ovat keskipakoisuus, kaukokaipuu, yhdellä hetkellä nähtävän maanpiirin ääreen kuviteltu onnenmaa, romantiikan keskeisimpiä aiheita. Kiven esikuva E. J. Stagnelius kaipasi "fjerran bort mot himlarandens blånad", ja jo paljon aikaisemmillakin runoilijoilla (esim. Dante, Milton) kukkaskedot ja vihreät kunnaat merkitsivät onnenmaata. Kiven asteittain etenevässä runossa kunnas on ensin vain maastonkohta, sitten "'k u i n Onnelan kaukainen maa", ja vihdoin kuva on tosi vain runon minän miellemaailmassa.

Onnela on kunnas ja lehto niin kuin Kiven monessa muussakin vastaavassa kuvitelmassa. Se esiintyy hänen jo varhain kirjoittamassaan ruotsinkielisessä runossa, joka on löytynyt Stagneliuksen Samlade skriftel -kokoelman kannesta. Löytöpaikka saattaa viitata siihen, mistä Kivi on saanut kirjallisia vaikutteita Onnela-kuvaansa. ${ }^{4}$ Sama

2 Paavo E. S. Elo, Aleksis Kiven persoonallisuus, s. 257.

3 Toive lentää länsituulen siivin onnenmaahan lienee Kiveen muutenkin vaikuttaneen Atterbomin perua: näytelmässä Lycksalighetens ö länsituuli kuljettaa Astolfin satujen saarelle.

${ }^{4}$ J. V. Lehtonen, Runon kartanossa, s. 7, 10-11, 432-433. 
onnenmaa on runoissa Helavalkea, Lintukoto, Sunnuntai ja Kesä-yö. Sillä ei ole mitään tekemistä reaalimaailman kanssa, jota Kiven lyriikassa edustavat honkanummi ja kanervakangas (Kanervakankaalla, Uudistalon perhe, Mies, Metsämiehen laulu, Kontiolan kaski, Kaukametsä - viimeksi mainittu lienee lähinnä tulkittava kristillisen ja maallisen onnenkäsityksen rajanvedoksi). Perimmältään samalta pohjalta lähtee Ensimmäinen lempi -runon kahtiajakoisuus: reaalisuutta edustaa havumetsä, unenomaista lemmenkaipuuta saarnisto. Honkanummi ja kanervakangas -tyyppi edustaa tosin myös Onnelaa, jonka ero kunnas ja lehto -tyyppiin verrattuna on sama kuin toden ja unen ero. Onnen kunnas tai lehto ei ole sään, vuorokauden eikä vuodenaikojen vaihtelun alainen; siellä vallitsee staattinen helluntai-ilta. Viimeistä edellisessä säkeistössä katse heilahtaa hieman kunnaan sivuun, laaksoon, jossa on keltakukkainen nuitty (vrt. runoa Kesäyö). Hämärän läpi näkyvät keltaiset kukat samoin kuin koko niityn yht'äkkinen mukaantulo runoon osoittavat, ettei kysymyksessä ole näkeminen, vaan haave.

Kivellä on kaksi unelmien Onnela-tyyppiä, joiden ero ei esim. Keinu-runossa ole selvä. Runo Lintukoto edustaa selvimmin sitä onnensaarta, jolla on suuri joukko vastineita Kiven aikaa varhaisemmassa maailmankirjallisuudessa (Novalis, Tieck, Heine, Byron, Atterbom, Stagnelius). V. Tarkiainen pitää skandinaavisia vaikutteita Kivelle merkittävimpinä. ${ }^{5}$ Paitsi asukkaita (Lintukodon kerikansa), yleiseen kuvaan kuuluu tietynlainen loisto ja värikkyys, ulkomaisilla kirjailijoilla nimenomaan eksoottisuus. Tätä edustaa Keinussa säe "kukkasil keltaisill". (Paitsi jo mainitussa Kesä-yö -runossa, Karkurien Elma uneksii paratiisista, jossa on "niittu kukkaskirjava".) Keinu-runossa on kuitenkin toisia, hallitsevampia piirteitä, Kiven toista Onnela-kuvaa. Sen piirteet ovat hämäryys, "unisuus" ja tasapainoinen tyydytys. Sillä on samoja tuntomerkkejä kuin Tuonelalla runoissa Ikävyys ja Sydämeni laulu. Tämä käsitepiiri ansaitsee tarkastelua, mutta sitä ennen on syytä huomata toinen kansanuskomukseen liittyvä piirre.

Romantiikan ajan kirjallisuus käyttỉ yhtenä materiaalinlähteenään kansanrunoutta, usein myös ulkomạista. Aleksis Kivi otti viro-

\footnotetext{
${ }^{5}$ V. Tarkiainen, Onnensaarj Kiven runoudessa. Aleksis Kiven muisto, s. $170-$ 174.
} 
laisen Koit ja Hämarik -tarinan Keinu-runoon (samoin runoon Kesäyö). ${ }^{6}$ Sen kesän kukkeimpana aikana ikuisesti toistuva eteerinen lemmenkohtaus on sinänsäkin saattanut viehättää Kiveä, ja ehkä osuutensa on silläkin tarinan puirteellä, jonka mukaan Koit ja Hämarik eivät halunneet tulla avioparilksi, vaan tahtoivat pysyä ikuisena morsiamena ja sulhasena, jollaisina he olivat löytäneet onnensa. Tämä kuva sopii sekä Kiven elämään että runon arkipakoisuuteen. Runon etenemisen kaavan kannalta viittaus kyseiseen tarinaan vie pääaiheen yhtä vaihetta kauemmaksi reaalisesta lähtökohdasta. Myytin sulautuminen aiheeseen lisää unelman epätodellisuutta. Koitin ja Hämarikin tarussa on erityisesti Keinu-runon Onnelan kuvaan sopivana piirteenä myyttiolentojen jokakeväiseen kohtaamiseen perustuva ikuisuus-motiivi. Ei ole kysymyksessä ihmisten, vaan jumalten maailma.

Ajan eliminoiminen tulee esille kaikissa jälkimmäisen jakson säkeistöissä ja nousee lopussa pääteemaksi. Samalla topografiset tuntomerkit katoavat. Kosmisen taruaiheen jatkona ovat säkeet: "Ja siel ijankaikkinen aika / Pois kiitävi vauhdilla kiitävän virran / Himmeään Unholaan." Nämä eivät ole aivan yksinkertaiset tullkita, mutta niissä on runon avain. Lauri Viljanen on välttänyt kaikkea konkretisointia: "... näky himmenee sisäiseksi haavemaisemaksi, jossa vallitsee ainainen kevät ja ainainen hämäryys." Hän puhuu vain ikuisuusmielialasta ja jatkaa: "Keinuhurmassa itse aika kadottaa pelottavuutensa, sen riento on niin nopeaa, että se on iankaikkisuutta, pelkkää himmeää unohdusta."т Tuskin Kivi kuitenkaan on huipentanut Onnela-kuvitelmaansa pelkkään kuvaukseen siitä, miten keinunta vaikuttaa. Hän olisi silloin särkenyt asteittain etenevän sarjansa. Koitin ja Hämarikin tarinaan tai sen henkeen ei kuulu

6 Tarinan on kirjoittanut muistiin Fr. R. Fählmann (1798-1850) : Jumalalla (Vanataat) oli kaksi kuolematonta orjaa, Koit ja Hämarik. H., tyttö, sai teh.täväkseen illalla sammuttaa laskevan auringon, Jumalan lampun, ja pitää siitä huolta. K:n oli määrä aamuisin sytyttää aurinko. Kun H. antoi lyhyenä kesäyönä auringon $\mathrm{K}: 11 \mathrm{e}$, he rakastuivat toisiinsa. Jumala toivoi $\mathrm{K}:$ sta ja $\mathrm{H}$ :sta tulevan avioparin. Nämä halusivat kuitenkin jäädä morsiameksi ja sulhaseksi, jollaisina. he olivat löytäneet omnensa. Jumala täytti heidän pyyntönsä, ja kerran vuodessa on neljän viikon aika, jolloin $K$. ja $H$. tapaavat toisensa sydänyöllä, puristavat kättä ja suutelevat. Tapaamisen kunniaksi Jumala koristaa kentät kauneimmilla kukillaan.

${ }^{7}$ Lauri Viljanen, Aleksis Kiven runomaailma, s. 142. 
mitään sellaista, mistä voidaan käyttää nimeä Unhola. Siksi näiden käsitteiden välissä täytyy olla etenevän kehityksen mukainen raja, viimeinen ennen absoluuttisen onnen määritelmää.

Kiven Onnela-käsite on yhteismitaton fyysisen elämän ja kuoleman kanssa. Elämän ja kuoleman välisen rajan liukeneminen on totaalisen onnentunteen edellytys, se on kliimaks. Kiven käsitys onnellisesta Tuonelasta perustuu lähinnä kansanrunon kehtolauluun "Tuuti lasta Tuonelaan". Tämä teema esiintyy Kivellä ensimmäisen kerran vuonna 1859 Eriika-kertomuksen käsikirjoituksessa. ${ }^{8}$ On huomattava, että paratiisi, jonka kanssa kirjallisuuden onnenmaalla on varsin paljon yhteistä, on kristillisen ja sitä tietä kansanomaisenkin käsityksen mukaan kuolemanjälkeinen asuinsija. Mm. Lehtonen korostaa Sydämeni laulusta puhuessaan haudantakaista rauhaa ja onnea maailman levottomuuden ja kaikkinaisen vaivan vastakohtana. ${ }^{9}$ Samalta kannalta on ymmärrettävissä J. Hollon käsitys iloisesta alistumisesta ja haaveen kultasillan rakentamisesta kohti Onnelaa, kun hän protestoi Tarkiaisen esittämää Sydämeni laulun tunnepohjaa. vastaan. ${ }^{10}$ Kuolema merkitsee Onnela-kuvitelmassa lähinnä lepoa, kaiken dynaamisuuden vastakohtaa. Keinu-runossa on huomattava onnenmaata kattava hämyvaippa; hämärä on sekä kansanrunoudessa että Kivellä Tuonelan epiteetti. Kansanperinteen monitahoinen ja moniselitteinen Tuonela on muutenkin kiinnostanut Kiveä kovasti. ${ }^{11}$ Onnela-kuvitelmissa se on enemmän yleistunnelmaan tarvittavaa miljöötä kuin varsinaista kuoleman valtakuntaa.

V. A. Koskenniemi sanoo Sydämeni laulua analysoidessaan: "Ei elämäntunteen heikkoudesta, ei elämän antimien kieltämisestä, vaan täyteläisestä, idyllisestä onnentunteesta on hänen laulunșa kuolemanakordi soinnahtanut, kuoleman, jonka onnesta täysi, rikas sydän sulkee elämän piiriin." ${ }^{12}$ On kuitenkin mahdollista, että Kiven runoissaan esiin tuoma, romantiikan olemukseen sopiva kaipaus pois arkitodellișuudesta olisi juuri elämän nurjien puolien vuoksi suuntautu-

\footnotetext{
${ }^{8}$ Lehtonen, mts. $82-89$.

Lehtonen, mts. $72-73$.

10 J. Hollo, Aleksis Kiven runot ja kirjeet, Valvoja 1916, s. 126--128.

11 Lehtonen, mts. 89-98. Lehtonen korostaa kirjallisten lähteiden (Kalevalan, Kantelettaren ja M. A. Castrénin teoksen Föreläsningar i finsk mytologi)

12 Koskenniemi, mts. 143.
} vaikutusta. 
nut ainakin osaksi fyysiseenkin kuolemaan, jonka hän olisi nähnyt yhtenä ratkaisuna. ${ }^{13}$

Aleksis Kivi on Keinu-runossa esittänyt Onnela-käsityksensä summan. Sen ainekset ovat romantiikan ja sitäkin aikaisemman kirjallisuuden enemmän tai vähemmän sensuaaliset onnenmaa-kuvitelmat, suomalaisen kehtolaulun onnellinen Tuonela, johon liittyy muunkin kansanrunon Tuonelan hämärä valööri, ja kristinuskon lupaus maailmaa paremmasta tuonpuoleisesta. Kaiken tämän otollisena kaikupohjana on ollut runoilijan halu paeta arkista todellisuutta sekä kaipuu rauhaan ja tasapainoon.

\section{Mauno Koski: The Island of the Blest in Kivi's Poem "Keinu"}

In Aleksis Kivi's poem "Keinu" (Swing), the first four lines of each verse contain a description of a landscape which is gradually changed into a vision of the Island of the Blest. The refrains relate the poem to time and place - a swing on a hill in the night in early summer - and they give the frame to the poem. The first four verses are a description of swinging and the atmosphere on the hill, and the last three verses represent the notion of the Island of the Blest. The maiden is present, but she is passive; the poem does not refer to any love dreams.

Kivi is observing the concrete landseape from high up and he sees vast views in all directions. In the development of the poem a part of the real landscape becomes, in the vision of the poet, the Island of the Blest. At the end, the picture is real only in the world of the poem.

Kivi has two types of Islands of the Blest. But the difference is not clear in "Keinu". One type has been influenced by counterparts in the world literature before Kivi's time. The Swedish poets Atterbom and Stagnelius have had the greatest influence on Kivi. In the poem "Keinu" there are other prominent features: twilight, sleepiness, and balanced satisfaction. Somewhat similar is the Tuonela (Realm of Death) in Kivi's poems "Ikävyys". (Loneliness) and "Sydämeni laulu" (The Song of My Heart).

The elimination of time is clear in the last three verses, and this becomes the main theme at the end. Also the real topographic features disappear. In the middle of the poem there is a reference to the Estonian story of Koit and Hämarik, which contains the motif of eternal renewal based on the return of mythic beings each spring.

${ }^{13}$ Samaa ajatusta tukee jossain määrin Kiven toveriensa nähden esittämä, toșin teatraalinen itsemurhaa valmistava kohtaus keväällä 1866, siis Kanervalan ilmestymisvuonna. V. Tarkiainen, Aleksis Kivi, elämä ja teokset, IV painos, s. 619 . 
Kivi's notion of the Island of the Blest is ineommesurable with physical life and death. In this poem the boundary between life and death is eliminated and the feeling of absolute happiness replaces it; this state of feeling is the climax of the poem. Kivi's notion of the happy Tuonela comes from the folk song "Tuuti lasta Tuonelaan". Also the Biblical Paradise is a Tuonela, a Realm of Death. The Realm of Death is enveloped by twilight both in folklore and in Kivi's poems. In Kivi's Island of the Blest, the Realm of Death is more like a necessary general atmosphere than a realistic afterworld. It is possible that Kivi's longing for the unreal, typical of romanticism, can be interpreted also as a death wish; as is well known, life was not kind to Kivi. 